\title{
Constraints to the Implementation of Effective Environmental Management in Coastal Areas of Developing Countries
}

\author{
ANGELA DE L.R. WAGENER \\ Departamento de Química, Pontifícia Universidade Católica do Rio de Janeiro, \\ Rua Marquês de São Vicente 225, Gávea, 22353-900 Rio de Janeiro, RJ, Brasil \\ Manuscript received on October 24, 2004; accepted for publication on May 18, 2005; \\ presented by JAILSON B. DE ANDRADE
}

\begin{abstract}
This paper addresses the limitations the scarcity of reliable scientific information poses to the implementation of effective and sustainable coastal management programmes in developing countries. Alternatives to the current monitoring approaches are suggested as to improve information level on the state of the environment and to decrease data gap on past conditions. The paper aims at encouraging the redesign of monitoring practices in developing countries as to be ground on the best actual scientific knowledge.
\end{abstract}

Key words: Coastal management, scientific information, environmental indicators, monitoring, developing countries.

\section{INTRODUCTION}

The natural environment functioning through an entangled network of interactions must be dealt with an integrated perspective (Bower and Turner 1998). Because integrated environmental concepts are rather recent, scientific tools available for the holistic understanding of environmental processes are still scarce. Progress towards integration requires new scientific approaches to ensure sustainability of resources and to attain the necessary integrated management (Healey and Hennessey 1994).

Coastal areas include sensitive environments (deltas, estuaries, etc.), which are subject to changes occurring on land and in the sea. The ideal management of these regions should include the whole area extending from the watersheds of the hydrographical basins to the external limits of the Exclusive Economic Zone (GESAMP 1996). However, there

E-mail: angela@rdc.puc-rio.br are rare successful examples of managing such large areas since various factors interfere in the process, as for instance: poor intergovernmental, intermedia, intersectorial and interdisciplinary integration (Knecht and Archer 1993); poor governance initiatives, lack of reliable data (Olsen 2001).

In addition, uncontrollable anthropogenic factors which are remarkable in developing areas, as for instance, population expansion and increasing trends of coastal occupation (Cohen et al. 1997, Alongi 1998) interacting with the complexity of the natural environment may undermine predictions (planning) as well as the outputs of management and conservation actions. Sustainability is especially sensitive to changes in demand upon natural resources (Pearce and Turner 1990) that, in turn, are strongly driven by these factors that are difficult to manage. Policymakers and managers in developing countries are continuously confronted with such uncertainties while proceeding often unaware of the 
benefits derived from an effective interaction with the science sector (Schwarzer et al. 2001) at an early stage of planning.

The present paper reviews and discuss two key factor witch impair the implementation of effective coastal management programmes in developing countries: the lack of monitoring strategies capable of increasing access to reliable knowledge, and barriers to the dissemination of scientific information needed to achieve outputs from national and international actions aiming at coastal conservation.

\section{EXISTING MONITORING REGIMES / ACTUAL NEEDS IN DEVELOPING WORLD COASTAL AREAS}

Lee (1993) proposes that integrated coastal management rely upon two pillars, the governance process and the reliable knowledge about the ecosystem functioning. In developing countries, information on the status and properties of the coastal environments are scarce. Actions towards mitigation and conservation cannot depend on the initiation of long-term data acquisition through scientific surveys which should have been conducted in the early stages of coastal occupation. However, properly designed monitoring activities carried out as a component of adaptative management may provide a substantial fraction of the required knowledge (Lee 1993).

Monitoring is a continuous process in time providing basis for evaluation and correction of management actions (Davenport 2003). The high costs associated to traditional methods of monitoring are constraining the use of continuous environmental observations in developing countries. Most frequently adopted procedures - often unsystematically - add very little information on the ecological integrity of the system under observation.

The recently introduced watershed management approach implies monitoring at medium scales (Boesch 1996) - for instance, a whole hydrographical basin as opposed to a single river or bay - a task that requires the development of observation and control systems effective at these scales.
The geographic magnitude of on going internationally funded activities in developing countries, as those in the São Francisco River Basin in Brazil $\left(640,000 \mathrm{~km}^{2}\right.$ of area) (United Nations Environmental Programme (UNEP)/Global Environmental Facility (GEF) Project: Integrated Management of Land Based Activities in São Francisco Basin) and in the Pantanal Upper Paraguay Transboundary River Basin $\left(496,000 \mathrm{~km}^{2}\right.$ of area) (UNEP/GEF Project: Integrated watershed management programme for the Pantanal and Upper Paraguay River Basin), imposes the implementation of complex monitoring arrays. In the case of the São Francisco River the construction of five dams endangers coastal stability and natural habitats in view of the steady reduction in sediment supply to the estuarine region, the decrease in water flow and changes in the flood regime (Medeiros and Knoppers, unpublished data). In spite of the existing scientific information demonstrating severe water depletion in this basin due to diverse uses, a programme has been considered to transpose water from the São Francisco River to a large and poor arid region in the Northeast of the country.

The feasibility of this programme strongly depends upon including the Tocantins River Basin (Araguaya-Tocantins Basin $-800.000 \mathrm{~km}^{2}$ ) in the management plan of the São Francisco, in addition to the reallocation of water resources and users coupled to a new policy for water distribution. In both basins, since anthropogenic activities also induce water contamination (mercury, pesticides, nutrients, trace metals) and decrease in water quality, an array of technical, social and legal interventions must be built in targeting the reduction of inputs and the introduction of monitoring. Evidently effective monitoring requires implementation of a robust observation network and adoption by all enrolled institution of common scientific approaches and standardised quality assurance practices.

Conventional water quality standards originally established for temperate environments 30 to 40 years ago have been later adopted in many de- 
veloping countries as guidelines to evaluate environmental conditions in coastal areas and to design monitoring programmes. Besides providing poor performance in coupling, for example, measured pollutant concentrations to a specific response in the ecosystem these standards are inadequate to identifying trends derived from continuous exposition to low or moderate levels of chronic stresses which may adversely affect biodiversity. There is an urge for revision of monitoring strategies as to include scientific tools (USEPA 2002) that: (1) are capable of providing information on adequate (or desirable) levels of environmental conditions and/or on changes in sustainability (or in the carrying capacity); (2) respond to early signs of alterations; (3) are flexible and robust as to be applicable under different settings.

Often environmental scientists are unable to provide managers and policy maker with fair estimates of "how much is too much" in terms of contamination (Cicin-Sain and Knecht 1998). This limitation has contributed to delaying the establishment of environmental thresholds and criteria based on actual knowledge.

For decades the sea was considered as the ultimate sink for sewage, litter and toxic residues. Although this view has progressively changed over the last 15-20 years often in developing regions financial limitations allied to poorly prepared personnel enrolled in managerial activities have led to continuing the practice of releasing wastes directly in estuaries and coastal areas. There is little awareness of inadvertent potential risks imposed by "traditional" sources of contamination, as for instance the domestic sewage.

The development of powerful analytical and assessment techniques in the last 20 years led to a significant advance in understanding of the complex composition of a number of contamination sources, and the dependence of cause-effect relationships on specificity of the source, of the contaminant, and of the recipient water body. This knowledge has not been fully integrated either in the management routine or in designing monitoring activities.

In many areas of the developing world, raw domestic sewage is directly delivered into coastal waters by means of submarine outfalls. Frequently drainage waters are also collected by such installations. As for the major sewage components, coastal dynamics may be sufficient to reduce nutrient concentration in recipient waters to an acceptable level but nitrogen species delivered by sewage (ammonia and urea) differs from the main nitrogen species (nitrate) in the ocean. This changed speciation superimposed to alterations in the nitrogen/phosphorus ratio leads to changes in ecological structure and to surges of unwanted opportunistic species (Smayda and Shimizu 1993). Although the bulk nutrient concentration may turn out within acceptable levels in dynamic coastal areas, the changing nutrient speciation and its ecological consequences may lead to ranking the resulting environmental risk as "too much".

For the manager and decision makers in developing countries the main concern is to give a final destination to waters enriched in nutrients, organic matter and pathogens with the lowest possible investment. In general, little, if any, attention is given to the complex composition of urban sewage and the associated risk of releasing persistent toxic substances or resistant micro organisms in the sea (Goldberg 1993).

In the large urban centres, drainage waters carrying polycyclic aromatic hydrocarbons, trace metals and pesticide residues are discharged through submarine outfalls or other discharge systems in association with the domestic sewage that also contain harmful substances (antibiotics, hormones, pesticide residues, chemicals used in household, cosmetics, etc.; some of them cannot be effectively removed by conventional treatments when those are at all available). Some of these substances are suspect to act as endocrine disrupters (Lye et al. 1999, Jobling et al. 1998) and little is known about the long-term effects they may have upon the marine biota, even at low concentrations. 
In the coastal area of Rio de Janeiro, Brazil, the two decades of a submarine outfall operation resulted in the build up of trace metal contamination in the surrounding waters (Wagener et al. 1992) and in the biota (Francioni et al. 2004) that eventually may return to man through the food web. Sediments contain polycyclic aromatic hydrocarbons (PAHs) at levels (256 ng.g ${ }^{-1}$; unpublished data) comparable to those reported for the heavily industrialized area of the Rhone (Lipiatou and Saliot 1991).

It is true that frequently poorer urban areas are not even served by sewage collection systems. In this case rivers, channels and drainage water contaminated with pathogens may flow with peak intensities during the tropical rain season directly into beaches and recreational waters. This is a severe threat to public health in urban centres, as in Rio de Janeiro, where beaches are a preferred recreational option for hundred of thousands. Water quality control based on E. coli counting, when present, may have minor impact in prevention of enteric diseases because of the usual long time lag between sampling and releasing balneability information to the public.

Last but not least, it is well known today that a number of virus and bacteria may survive longer in seawater than expected earlier when recreational water criteria were solely based on faecal coliforms. Health risk related to bathing in contaminated seawater or eating raw seafood may be, therefore, greater than presumed (Murray and Lopez 1996, CGER 1999). In this concern more adequate criteria must be tested in developing regions and adopted to protect human health (WHO 2003).

A serious barrier to management of coastal areas in developing countries arises from lack of funding mechanisms to support the acquisition of time series data and continuous monitoring. Data collection often fragmented fails in the necessary robustness to support trend recognition and forecasting.

Also in the industrialised countries, the relatively late implementation of continuous observation activities at the national and regional levels resulted in the scarcity of long term data characterising cross-interactions among contaminants/anthropogenic induced stresses, natural variations, and the ecosystem (Rabalais et al. 2000).

A successful example of continuous observations is the National Status and Trends Program established in 1984 to provide long term dataset to track changes in the US coastal environmental quality. This programme includes two on going projects, The Mussel Watch Project and the Bioeffects Assessment Project, and the Benthic Surveillance Project terminated in 1993. The two on going projects aim at monitoring organic and inorganic contaminants in sediment and bivalve samples from coastal waters of US as a basis to identifying risk areas. The importance of long term observation is highlighted by the conclusion drawn that it was possible to determine existing environmental trends only for sites at which six or more years of data are available (Lauenstein and Cantillo 2002).

In the developing countries long term observations are virtually absent although they are vital to understanding the chronic effects of pollution and other disturbances upon the aquatic ecosystems.

For instance, the long term effects of eutrophication are little known although nutrient enrichment is a major problem of global importance because of the effects on the metabolism of aquatic systems (Kemp et al. 1997). The immediate responses to increased nutrient load, as the decrease in dissolved oxygen, tendency to hypoxia and appearance of alga blooms are well documented (Officer et al. 1984, Rebello et al. 1988, Turner and Rabalais 1994, Balls et al. 1995, Howarth et al. 2000). More difficult to access are the long-term effects upon species at several trophic levels and the losses in biodiversity for which the economic consequences must still be quantified. A strong example of such alterations occurred in Guanabara Bay, an urban estuary in Rio de Janeiro, Brazil, where eutrophication has often led to the surge of unwanted toxic algae species followed by fish mortality and to a major contribution of cyanobacteria to the algae pool (Valentin et al. 1999). Nowadays, gastropods (Stramonita haemas- 
toma) and molluscs (Perna perna) cannot be found in the inner and most contaminated regions of the bay where they were abundant in the past.

Recent investigations in sediment cores showed an additional but less obvious change in Guanabara Bay, a 10-fold increase in the sedimentary carbon and nutrient pool that occurred over the last 50 years (Carreira et al. 2002) as resulting from the increment in carbon fixation allied to high sedimentation rates (1-2 cm.year $\left.{ }^{-1}\right)$. Time trends of coprostanol, a faecal molecular marker, and other sterols recorded in dated sediment cores confirmed the link between these increments and the increasing sewage contamination in Guanabara Bay (Carreira et al. 2004).

Geochronological investigations, as these cited above, have been useful in elucidating trends and past environmental conditions (Valette-Silver 1993). Recent advances in the field of organic geochemistry may credit new dimension to investigations aimed at understanding time changes in species dominance and alterations in the productivity/respiration ratio resulting from eutrophication. Chemical molecules reasonably well preserved in sediments that can be traced back to original substances produced by specific organisms - bacteria, cyanobacteria, diatoms, dinoflagellates, etc - (Bianchi and Canuel 2001, Zimmerman and Canuel 2002, Carreira et al. 2002) appear as powerful tools in monitoring these changes. Investigations applying such tools in dated sediment cores are capable of reproducing trends derived from increased nutrient loads and demographic growth. In very altered coastal ecosystems, for instance, this information allied to statistical data on source intensity and demographic/agriculture growth are essential for the understanding of threshold levels that triggered substantial or even irreversible changes. Managers should make use of such information to support objective decisions on the appropriate/desirable carrying capacity that must and can be recovered, and estimate the necessary investments.

A substantive problem in tropical coastal systems is the increase in sedimentation rates due to deforestation and improper soil management/ occupation (Rebello et al. 1986, Godoy et al. 1998). The increased sedimentation poses at least three major problems: the loss of habitat, the decrease in recreational and economically useful area and the increment of toxic substances stored in sediments (Charles and Hites 1987, Cleverly et al. 1996). Geochronology also aids in estimating fluxes from contaminated sediments that may be an important supply of nutrients, as forecasted for Guanabara Bay (Rebello et al. 1988), and toxic substances long after the land sources have been reduced. Decisions on the use of expensive but safe procedures of removing contaminated sediments and rehabilitating silted areas should be based upon this source strength knowledge as to evaluate cost/benefit. Environmental liabilities maybe estimated from such observations, and reductions in sediment loads in response to reforestation program or to adequate soil management can easily be verified.

\section{PROMISING MONITORING TECHNOLOGIES FOR COASTAL AREAS}

The conventional environmental indicators (BOD, dissolved oxygen, bulk nutrient concentration, particulate matter, faecal coliforms) most frequently applied to monitor areas subjected to domestic sewage inputs do not address the above issues. They also fail in expressing vital systemic changes in the environment and the consequent impact on the biota or the actual risk to human health (Paul et al. 1997). This is a common limitation of most environmental indicators under current use, which are solely based upon monitoring concentration changes in environmental compartments.

The biomarker concept that advanced rapidly over the last decade may become a useful tool in the observation of systemic changes occurring in marine ecosystems and, therefore, in coastal management. The concept is based on biological or/and biochemical expressions appearing as a response from organisms to exposure to contaminants and other environmental stresses (Depledge and Fossi 1994, 
Depledge et al. 1995, Fossi et al. 2000). The great majority of the already tested biomarkers responds to more than one group of stressing forces, and the more specific the tests the higher are the costs of use and technical expertise required. There are, however, robust biomarkers that are suitable indicators of stressing environmental conditions although less intensive on costs/technical expertise. The micronucleus assay (Brunetti et al. 1998) that responds well to exposure to carcinogenic substances and the nonspecific lysosoma assay (Cheung et al. 1998) are some examples of tests that may suit well conditions in developing countries.

Both these tests were successfully applied in monitoring impacts derived from oil spills in Guanabara Bay, Rio de Janeiro. Mussels Perna perna have proved to be excellent biomonitors for oil contamination in the bay since their PAHs bioaccumulation follows closely concentration changes in the water column with little departure from the original oil composition (Francioni et al. 2005). The analysis of polyaromatic hydrocarbons in mussel tissue is costly especially if alkylated polycyclic aromatic hydrocarbons are included as required in chemical forensics. Preliminary results obtained by applying the neutral red (lysosoma assay) in mussels Perna perna from contaminated and uncontaminated areas demonstrated the good performance of this inexpensive approach to monitor acute oil releases. Organisms in pristine areas showed long retention times for neutral red in the lysosoma compartments but because of the chronic contamination state in Guanabara Bay low retention times are continually observed in the mussels from the bay. The usual statistical distribution of the retention times for each observed population shows a wide range of values as expected in biological systems exposed to steady state conditions. Nevertheless, after an oil spill in January 2000 data distribution for the sampled population in the bay was strikingly different although average retention times were in the range observed prior to the spill. The oil spill caused a three-fold increase in PAH concentration (from an average of
$500 \mathrm{ng} \cdot \mathrm{g}^{-1}$ to $1700 \mathrm{ng} \cdot \mathrm{g}^{-1}$ ) in the mussels and the individually different responses to the neutral red assay were cancelled out (from an average variance of $42 \%$ to 0 ). The phenomenon that there was no distribution of the results may result from a threshold reaction indicative of particularly altered environmental conditions (Francioni et al. 2005). These useful observations provided a basis for the safe application of the technically simple and inexpensive neutral red test to monitor acute events in this chronically altered bay.

The managerial value of biomarkers also relies on the possibility to detect biological responses at early stages of environmental changes. Moreover, different from usual ecotoxicology assays, they are applied in population samples exposed to the in situ conditions. The concurrent evaluation of concentration levels of suspected contaminants contributes to the gradual establishment of more adequate environmental criteria. Besides the information on the status of individual species, when applied on a continuous basis to organisms selected as to represent different trophic levels, biomarkers are likely to be useful in recognizing trends of systemic changes. The tests are also useful in controlling illegal releases of contaminants in areas subject to conservation activities and as means to obtain early warnings on changes in pristine regions.

Immunoassays based on enzymatic or antigenic reactions are promising tools to be applied in monitoring (Meulenberg et al. 1995, Waters et al. 1997, Barceló et al. 1998). A number of commercially available kits has been validated for direct application. The immunoassay test is less expensive than a traditional complete chemical analysis - as for instance for pesticides and polycyclic aromatic hydrocarbons (15 US dollars as compared to 180 US dollars for the complete chemical analysis); its application requires some training but is less labour intensive than most analytical procedures; it can provide quasi real time data; and reproduce a biochemical reaction to a toxicant. Because of possible crossreactivity immunoassays are more suitable for appli- 
cation in routine monitoring, when base line data are already available, or in the inspection of large areas to identify hot spots. Francioni et al. (2003) used the test that responds to BTEX to localise hot spots of gasoline contamination in soils and compared the results with those from traditional chemical analysis obtaining a linear correlation coefficient $\left(r^{2}\right)$ of 0.998. Even substances that are difficult and expensive to monitor, as dioxins, are potential candidates to be currently detected by immunoassays in the near future. In developing regions where funds and lack of sufficient trained personnel are limiting the scope and frequency of monitoring activities, the use of immunoassays is an interesting option for environmental screening.

\section{ADDITIONAL BARRIERS}

Coastal managers and environmental agencies in developing countries have to deal with institutional and economic limitations; however, a key constraint to the effective management is the difficult access to scientific information (Millard and Sayers 1999).

The capability to organise the existing information as to allow causal chain identification through a cross-linking of events (for example, the relation between level of sewage contamination in the beaches and the number of working hours lost due to enteric diseases) is also deficient. There is an obvious need for improving the access to scientific information in a comprehensive format useful to managers (Schwarzer et al. 2001).

Tackling this problem requires first a revision of strategies so far dominant in the ways scientific information is disseminated. Emeis et al. (2001) considered that communication of scientific issues to managers is humped due to controversy and conflicting signals among other factors. In many developing countries communication turns out intrinsically difficult due to other factors in addition, as for instance, the use of international journals as the unique channel to convey scientific findings. Managers and decision makers in such countries usually have no easy access to these journals and neither are they trained to extract useful information from these publications directed to the scientific community. Information of so-called local interest do not reach acceptance in a number of international journals and may rest unreachable to the interested user if not even a national or regional scientific publication system is in place. Furthermore, it is truth that in the so-called century of communication many areas of the world have no straightforward access the abundant information in the Internet.

There is a great need to bring up scientific communication directed to non-scientists in the developing countries, including capacity building at the media level. The media contribution to the dissemination of local or regional scientific advances to the public in general is scarce or of very poor quality. It fails in raising awareness and in contributing as it could to foster public and private investments in the science sector. Internationally funded projects are rarely addressing this issue although they often deal with capacity building initiatives.

A consensus does not yet exist on the best procedure to adopt in communicating scientific facts to managers, policy makers and other stakeholders, therefore different modalities should be adapted to the local/regional cultural, social and political scenario. Nevertheless, the resulting communication instrument should be flexible and independent as to allow free flow of ideas and information.

In developing countries the performance of regulatory environmental agencies is deeply subjected to the will of the actual political current in power. Effectiveness of communication may be affected by the fragility of these important institutions. Recent experiences gained in assessment projects carried out in the Todos os Santos Bay, Bahia (Wagener et al. 2003), and Guanabara Bay, Rio de Janeiro (Wagener et al. 2002), revealed that although the same set of communication instruments (meetings, reports seminars) have been used in both cases the supportive political atmosphere in Bahia was a key factor ensuring the strong commitment of the state environmental agency that, in turn, greatly 
facilitated a successful interaction with scientists.

Appropriate grounds for testing and stimulating different communication approaches are the Global Environmental Facility (GEF) funded projects because of the available organisational infrastructure and the potential to agglutinate different sectors at the local and regional scale.

These projects offer, in addition, the proper ground to test monitoring approaches that include participation of members of the local communities. Although in recent years indigenous knowledge emerged as a desirable component of internationally funded projects in developing countries little guidance has been given to create greatly needed job opportunities through the formal hiring of community members to perform simple but effective monitoring practices. There are, however, examples of community volunteers carrying out water quality monitoring as in the case cited above of the São Francisco River project. From top to down in the scale of complexity a number of opportunities not yet experienced in coastal management in developing countries is available to ensure feasibility, good performance and sustainability of monitoring activities.

\section{CONCLUSIONS}

The coastal environmental problems in developing countries are increasing dramatically as a result of the uncontrolled population growth and unsustainable development practices. Monitoring the environmental alterations, as a necessary basis for planning mitigation actions and source reduction, is a challenge under the present settings of deficient technical and economic capabilities in these countries. These shortcomings can be partly overcome by making use of fast screening methods, which are based, for instance, on biomarkers of stress and immunoassays, enrolling community members in the process and improving interaction among policy, managerial and scientific sectors. Still, practices, criteria and regulations adopted in developed countries must undergo a critical evaluation as for their suitability to current natural and economic condi- tions before acceptance in developing tropical areas. In this regard, introduction of local scientific knowledge in the formulation of regulatory instruments related to impact assessments and monitoring represents an important step forward in identifying site-specific needs and useful tools.

\section{RESUMO}

O presente texto trata das limitações, impostas pela escassez de informação científica confiável, à implementação de programas eficazes e sustentáveis de gestão costeira em paises em desenvolvimento. São sugeridas alternativas às abordagens correntes de monitoramento, as quais visam aprimorar o nível de conhecimento sobre o estado do meio ambiente e decrescer a carência de dados sobre suas condições pretéritas. As discussões apresentadas pretendem encorajar o redesenho das práticas de monitoramento em países em desenvolvimento de forma que passem a se fundamentar no melhor conhecimento científico atual.

Palavras-chave: Gerenciamento costeiro, informação científica, indicadores ambientais, monitoramento, países em desenvolvimento.

\section{REFERENCES}

AlOngi DM. 1998. Coastal ecosystem processes, Boca Raton, CRC Press Inc.

Balls PW, MacDonald A, Pugh K and Edwards AC. 1995. Long-term nutrient enrichment of an estuarine system: Ythan, Scotland (1958-1993). Environ Poll 90: 311-321.

Barceló D, Oubiña A, SAlau JS And Perez S. 1998. Determination of PAHs in river water samples by ELISA. Anal Chim Acta 376: 49-53.

Bianchi TS And CANUEl EA. 2001. Organic geochemical tracers in estuaries. Org Geochem 32: 451.

BOESCH DF. 1996. Science and management in four U.S. coastal ecosystems dominated by land-ocean interactions. J Coast Conserv 2: 103-114.

BOWER BT AND TURNER RK. 1998. Characterising and analysing benefits from integrated coastal management. Ocean Coast Manage 38: 41-66.

Brunetti R, Majone F, Gola I AND Beltrame 
C. 1998. The micronucleus test: examples of application to marine ecology. Mar Ecol Prog Ser 44: $65-68$.

Carreira R, Wagener A de LR, Readman JW, Fileman TW, Macko S AND VeIGa A. 2002. Changes in the sedimentary organic carbon pool of a fertilised tropical estuary, Guanabara Bay, Brazil: an elemental, isotopic and molecular marker approach. Mar Chem 79: 207-227.

CARreira RS, WAgener A DE LR, REAdMAN J AND FILEMAN T. 2004. Coprostanol as marker of sewage contamination in a tropical urban estuary (Guanabara Bay, Brazil): space-time variations. Estuarine, Coastal and Shelf Science 60: 587-598.

CGER (COMMISSION ON GEOSCIENCES, ENVIRONMENT AND RESOURCES). 1999. From monsoons to microbes: understanding the ocean's role in human health, Washington DC, The National Academy Press.

Charles MJ and Hites RA. 1987. Sediments as archives of environmental pollution trends. In: Hites RA AND EISENREICH SJ (Eds), Sources and fates of aquatic pollutants, Amer Chem Soc.

Cheung VV, Wedderburn RJ And Depledge MH. 1998. Molluscan lysosomal responses as diagnostic tool for the detection of a pollution gradient in Tolo Harbour, Hong Kong. Mar Environ Res 46: 237241.

CiCIN-SAIN B AND KNECHT RW. 1998. Integrated coastal and ocean management. concepts and practices, Washington, DC, Covelo Island Press.

Cleverly D, Monetti M, Phillips L, Cramer P, Heit M, McCarthy S, O’ Rourke K, Stanley J AND WINTERS D. 1996. A time-trend study of the occurrences and levels of CDDs, CDFs and dioxinlike PCBs in sediment cores from 11 geographically distributed lakes in the United States. Organohalogen Compounds 28: 77-82.

Cohen Je, Small C, Mellinger A, Gallup J, SACHS J, VitouseK PM AND MoOney HA. 1997. Estimates of coastal population. Science 278: 1209-1213.

DAVENPORT TE. 2003. The watershed project management guide, Boca Raton, CRC Press.

Depledge MH AND Fossi MC. 1994. The role of biomarkers in environmental assessment (2). Invertebrates Ecotoxicol 3: 161-172.

DEPlEdGE MH, AAGAARD A AND GYÖRKöS P. 1995. Assessment of trace metal toxicity using molecular, physiological and behavioural biomarkers. Mar Poll Bull 31: 19-27.

Emeis KC, Benoit JR, DeEgan LA, Gilbert AJ, Lee V, McGlade JM, Meybeck M, Olsen SB AND VON BODUNGEN B. 2001.Unifying concepts for integrated coastal Management. In: vON BODUNGEN B AND TURNER RK (Eds), Science and integrated coastal management, Berlin, Dahlem University Press.

Fossi mC, Casini S, Savelli C, Corbelli C, Franchi E, Mattei N, SANCHEZ-Hernandez JC, Corsi I, Bamber S AND Depledge MH. 2000. Biomarker responses at different levels of biological organization in crabs (Carcinus aestuarii) experimentally exposed to benzo[a]pyrene. Chemosphere 40: 861-874.

Francioni EL, Hamacher C, Wagener A DE LR, Depledge M, Fileman G and Guadalupe F. 2003. Evaluation of commercially available ELISA kits as a tool to determine BTEX in groundwater. Environ Technol 24: 665-670.

Francioni EL, Wagener A de LR, Calixto RC AND BAstos G. 2004. Evaluation of Perna perna (Linné, 1758) as a tool to monitoring trace metals contamination in estuarine and coastal waters of Rio de Janeiro, Brazil. J Braz Chem Soc 15: 103-110.

Francioni EL, WAGENER A DE LR, SCOFIELd A DE L AND CAVALIER B. 2005. Biomonitoring of Polycyclic Aromatic Hydrocarbon in Perna perna (Guanabara Bay, Brazil), Environ Forensics (in press).

GESAMP (JOINT GROUP OF EXPERTS ON THE SCIENTIFIC ASPECTS OF MARINE ENVIRONMENTAL Protection). 1996. The contributions of Science to integrated coastal management. Reports and Studies nr. 61, Rome, FAO.

Godoy JM, Moreira I, Wanderley C, Mendes LB AND BRAGANÇA MJA. 1998. Study of Guanabara Bay sedimentation rates. J Radioanal and Nucl Chem 227: 157-160.

GoldBerg ED. 1993. Competitors for coastal ocean space. Oceanus 36/spring. 
Healey MC And Hennessey TM. 1994. The utilization of scientific information in the management of estuarine ecosystems. Ocean Coast Mange 21: 157191.

Howarth RW, Jaworski N, SWANEy D, TOWSEND A AND Billen G. 2000. Some approaches for assessing human influences on fluxes of nitrogen and organic carbon to estuaries. In: HobBIE JE (Ed), Estuarine science a synthetic approach to research and practice, Washington DC, Island Press.

Jobling S, Nolan M, Tyler CR, BRighty G AND STUMPTER JB. 1998. Widespread sexual disruption in wild fish. Environ Sci Technol 32: 2498-2506.

Kemp WM, SMith EM, MaRVin-Dipasquale M AND BOYNTON WR. 1997. Organic carbon balance and net ecosystem metabolism in Chesapeake Bay. Mar Ecol Prog Ser 150: 229-248.

KNECHT RW AND ARCHER J. 1993. "Integration” in the US coastal zone management program. Ocean \& Coast Manage 21: 183-199.

Lauenstein GG and Cantillo AY. 2002. Trends in the US national estuarine research reserves, NOAA NOS Technical Memorandum, NCCOS 156.

LEE KN. 1993. Compass and gyroscope: integrating science and politics for the environment, Washington DC, Island Press.

Lipiatou E AND SALIOT A. 1991. A Hydrocarbon contamination of the Rhone delta and the open western Mediterranean. Mar Pollut Bull 22: 297-304.

LYE CM, FRID CLJ, GILl ME, COOPER DW AND JONES DM. 1999. Estrogenic alkylphenols in fish tissue, sediments and waters from the UK Tyne and Tees estuaries. Environ Sci Technol 33: 1009-1014.

Meulenberg EP, Mulder WH And Stoks PG. 1995. Immunoassays for pesticides. Environ Sci Technol 29: 553-561.

Millard K And SAYers P. 1999. Maximising the use and exchange of coastal data, London, CIRIA.

MurRAY CJL AND Lopez AD. 1996. The global burden of disease, Cambridge Harvard School of Public Health .

OfFicer CB, Biggs RB, TAFT JL, CRONIN LE, TYLER M AND BOYNTON WR. 1984. Chesapeake Bay anoxia: origin, development and significance. Science 223: 22-27.
OLSEN SB. 2001. Inventing governance systems that respond to coastal ecosystem change. In: vON BoDUNGEN B AND TURNER RK (Eds), Science and integrated coastal management, Berlin, Dahlem University Press.

Paul JH, Rose JB, Jiang SC, London P, Xhon X AND Kellog C. 1997. Coliphageand indegenous phage in Manala Bay, Hawaii. Appl Environ Microbiol 63: 133-138.

Pearce DW and Turner RK. 1990. Economics of natural resources and the environment, London, Harvest Wheatsheaf.

Rabalais NN, Turner RE, Justic D, Dortch Q, WisEMAN WJ AND Gupta BA. 2000. Gulf of Mexico biological system responses to nutrient changes in the Mississipi River. In: HobBIE JE(Ed), Estuarine science, Washington DC, Island Press.

Rebello A de L, Haeckel W, Moreira I, SANTELLI R AND SCHROEDER F. 1986. The fate of heavy metals in a tropical estuarine system. Mar Chem 18: 215-225.

Rebello A de L, Ponciano C and Melges lhF. 1988. Primary production and availability of nutrinets in Guanabara Bay. An Acad Bras Cienc 60: 419-430.

SCHWARZER K, CRossland CJ, WAgener A DE LR, de Vires I, Dronkers J, Penning-Rowsell E, REISE K, SARdÁ R, TAUSSIK J AND WASSON M. 2001. Shoreline development. In: VON BODUNGEN B AND TURNER RK (Eds), Science and integrated coastal management, Berlin, Dahlem University Press.

SMayda TJ AND ShimizU Y. 1993. Toxic Phytoplankton in the Sea, Amsterdam: Elsevier.

TURner RE AND RABALAIS NN. 1994. Coastal eutrophication near the Mississipi River delta. Nature 368: 619-621.

USEPA (United States Environmental ProtecTION AGENCY). 2002. Research strategy - environmental monitoring and assessment program, EPA00/R-02/002.

Valentin JL, Tennebaum DR, Bonecker A, BoNECKer SLC, Nogueira CR ANd VILlaC MC. 1999. Characteristiques hydrologiques de la baie de Guanabara (Rio de Janeiro, Brésil). J Res Oceanogr 24: $33-41$. 
VALETTE-SILVER NNJ. 1993. The use of sediment cores to reconstruct historical trends in contamination of estuarine and coastal sediments. Estuaries 16: 577588.

Wagener A de LR, Bouch C, Melges-FigueiREDO LH AND WAGENER K. 1992. Environment impact on coastal waters off Rio de Janeiro due to sewage discharge via submarine outfall. Chem Ecol 6: 19-39.

Wagener A de LR, Scofield A, Hamacher C, Francioni E, CARreira R AND CARdoso J. 2002. Avaliação de danos causados pelo derramamento de óleo, em janeiro de 2000, na Baia de Guanabara - monitoramento químico. Secretaria de Meio Ambiente e Desenvolvimento Social, Rio de Janeiro, RJ, Brasil.

WAgener A De LR, Scofield A, Hamacher C, Miekeley N, Campos R, Godoy J, Francioni E and Vergueria S. 2003. Diagnóstico do grau de contaminação da BTS por metais pesados e hidrocarbonetos de petróleo a partir da análise das suas concentrações nos sedimentos de fundo e na biota associada - diagnóstico químico. Centro de Recursos Ambientais, Consorcio Hydros/CH2M-Hill, Bahia, Brasil.
Waters LC, Palausky MA, Counts RW AND JENKINS RA. 1997. Performance of commercially available immunoassay-based field test kits for petroleum fuel hydrocarbons in soil. Field Anal Chem Tech 1: 135-144.

WHO. 2003. Guidelines for Safe Recreational Environments. Volume1: Coastal and freshwaters, Geneva.

ZimMERMAN AR AND CANUEl EA. 2002. Sediment geochemical records of eutrophication in the mesohaline Cheasapeak Bay, Limnol Ocean 47: 1084-1093. 